\title{
The Funnel Beaker and Globular Amphora Cultures in the Sandomierz Upland in the Light of Settlement Research
}

\section{Hanna Kowalewska-Marszałek ${ }^{a}$}

\begin{abstract}
The article concerns the Neolithic settlement structures of the Funnel Beaker and Globular Amphora cultures in the Sandomierz Upland, discussed comparatively in the context of interrelationships and relationships with the exploitation of flint raw materials, especially of banded flint.
\end{abstract}

KEY-WORDS: Funnel Beaker culture, Globular Amphora culture, Sandomierz Upland, Neolithic settlement, flint raw materials.

\section{INTRODUCTION}

The Sandomierz Upland - a mesoregion in the current physical and geographical division of Poland (Kondracki 1978: 36I), limited by the valleys of the Vistula and Kamienna rivers and the range of the Świętokrzyskie Mountains, covering an area of about IIOo $\mathrm{km}^{2}$ - was and is considered one of the key regions for research on Neolithic. Its importance was noticed and appreciated quite early by researchers studying the Late Stone Age, which resulted in undertaking many pieces of fieldwork and the accumulation of a large amount of material evidence. This provides a good starting point for further research, including on the long term evolution of settlement in the Neolithic. It has become possible to trace the variability of settlement structures at various levels of complexity, as well as to determine the nature and direction of settlement processes (Kowalewska-Marszałek 1992). On the other hand, a major difficulty is generally the rather imprecise dating of finds, limiting the scope of considerations to the main taxonomic units of the Neolithic.

a Institute of Archaeology and Ethnology Polish Academy of Sciences, IO5, al. Solidarności, OO-I40 Warsaw, Poland, e-mail: hanna@iaepan.edu.pl ORCID: oooo-ooo2-7356-1402 
I20 $\mid$ Hanna Kowalewska-Marszatek

THE SANDOMIERZ UPLAND IN THE RESEARCH OF JAN KOWALCZYK

In the 1960s, the Sandomierz Upland also became an object of interest on the part of Jan Kowalczyk, who undertook methodical research activities here, referred to as the "field survey" (Kowalczyk 1962). They consisted of a preliminary, partial survey of a single site or area, which was supposed to initiate the outline of problems and allowed the researcher a holistic view of the situation (Kowalczyk 1962: 30I). According to J. Kowalczyk, this was a particularly important approach considering the contemporary state of research on the Neolithic.

An important issue was the selection of a suitable area. J. Kowalczyk believed the Sandomierz Upland and the areas adjacent to it to be one such area, due to the concentration of very diverse soils and geomorphological elements (Kowalczyk 1962: 302). An additional advantage were the historical and geographical elements: the location at the intersection of an important Vistula water route with the Vistula and San water junction and the east-west land route (Kowalczyk 1962: 302), as well as the proximity of flint raw material deposits.

Therefore, inspired by J. Kowalczyk (in 1962), surface prospecting along the lower Opatówka river and in the area of Annopol and Świeciechów, Kraśnik district was begun, and in the following years excavations of several key Neolithic sites were undertaken: Funnel Beaker culture settlements in Kamień Łukawski (Kempisty 1965) and in Zawichost-Podgórze (Balcer 1967), Sandomierz district and a flint mine in Świeciechów-Lasek, Kraśnik district (Balcer 197I). The results of this work, carried out over several seasons, are today the basis for many important findings. They also became the starting point for a broader reflection, including on the issue of "central settlements" in the Funnel Beaker culture, the issue of the relationship between the latter and the Globular Amphora culture, and the problem of the exploitation of flint raw materials by the communities of both cultures. These issues, signalled by J. Kowalczyk (1962: 304, 306), were analysed and discussed in later studies (cf. e.g. Tabaczyński 1970; Balcer 2002; Nowak 2009). Some details are also added by the studies on the Neolithic settlement of this region (Kowalewska-Marszałek 1992).

\section{SETTLEMENT OF THE FUNNEL BEAKER CULTURE}

The Sandomierz Upland is an area of compact, intensive settlement of the Funnel Beaker culture, the sites of which constitutes over $40 \%$ of all known, culturally defined

I These studies are based on data concerning the whole area of the Sandomierz Upland in its geographic boundaries. The detailed data specified in the tables were obtained from an area systematically investigated $\left(773 \mathrm{~km}^{2}\right)$, mainly during a systematic fieldwalking survey, that is thought to be representative of the whole Upland. 
settlement points ${ }^{2}$ from this region. The settlement network is made up of settlements, camps, workshops, cemeteries, graves, "hoards" (deposits) and undetermined traces of settlement (Table I). The range of their occurrence covers the entire area of the Upland, but they are concentrated mainly in its central and, to a lesser extent - in the northern part; there too are the regions with the highest density of sites (Fig. Ia). The distribution of settlement points shows a division into three zones: northern, central and southern. The average density is almost 60 sites per $100 \mathrm{~km}^{2}$, i.e. one site per 1.7 $\mathrm{km}^{2}$ (Table 2); the largest is visible on the upper Gorzyczanka river (Fig. 2a). Larger concentrations also occur in the upper parts of the Kamionka river basin, the Opatówka river basin and some sections of the Vistula escarpment (in the vicinity of Złota, the area between the Pepper Mountains north of Sandomierz and Zawichost, Sandomierz district).

The results of the analysis of the spatial distribution of settlement points carried out using the Clark-Evans ${ }^{3}$ test indicate a poorly agglomerated system (coefficient $\mathrm{R}=0.87$ ), close to random (Table 3). This situation differs from that observed in the loess highlands in the western parts of Lesser Poland, where the results obtained using the same test confirmed a rather regular, non-random points system ( $\mathrm{R}=$ I.499; Kruk I980: 78).

The distribution of settlements which constitute slightly less than half of all settlement points of the discussed culture and are diversified in size is interesting ${ }^{4}$. They occur throughout the entire Upland, mainly in the central zone, and their more pronounced concentration is visible on the upper Kamionka river. In the central-western zone, as well as in the northern one, large settlements are most common, while in the central-eastern area medium-sized settlements predominate (Fig. 3a). The distribution of large and medium settlements exhibits the features of a regular system, in the case of medium settlements this regularity is even more pronounced (Table 3). This suggests the existence of a clearly defined "settlement pattern", largely independent of specific geographical and natural conditions. This is also confirmed by data on the relationships between the Funnel Beaker culture settlement network and individual elements of the natural environment (Kowalewska-Marszałek 2018: 315).

2 The term "settlement point" as defined by Kazimierz Godłowski (1964: 40I); see also the comments of Janusz Kruk (1973: 30).

${ }_{3}$ Clark-Evans coefficient, allowing drawing conclusions about the nature of the system of points: random $(\mathrm{R}=\mathrm{I})$, regular $(\mathrm{R}>\mathrm{I})$ or agglomerated $(\mathrm{R}<\mathrm{I})$, (cf. Hodder and Orton 1976: 40).

4 The division of settlements was adopted into small (up to 0.5 ha), medium (0.5-2 ha), large (2-5 ha) and very large (over 5 ha; Kowalewska-Marszałek 1992: 156). 
Table I. Sandomierz Upland - categories of settlement points of the Funnel Beaker and Globular Amphora cultures (according to Kowalewska-Marszałek 1992: Table 7).

\begin{tabular}{|c|c|c|c|c|c|}
\hline $\begin{array}{l}\text { Category of settlement } \\
\text { points }\end{array}$ & $\begin{array}{l}\text { Funnel } \\
\text { Beaker } \\
\text { culture }\end{array}$ & $\begin{array}{c}\text { Funnel } \\
\text { Beaker } \\
\text { culture? }\end{array}$ & $\begin{array}{c}\text { Globular } \\
\text { Amphora } \\
\text { culture }\end{array}$ & $\begin{array}{c}\text { Globular } \\
\text { Amphora } \\
\text { culture? }\end{array}$ & Total \\
\hline Settlement & $197+31 ?$ & $9+4 ?$ & $33+14 ?$ & 1 ? & 289 \\
\hline Camp & $10+3 ?$ & 6 & 1 & 1 & 21 \\
\hline Settlement and grave & 8 & - & 3 & - & 11 \\
\hline Workshop-type settlement & 12 & 3 & 1 & - & 16 \\
\hline Cemetery & 7 & 2 & 4 & - & 13 \\
\hline Grave & 4 & 1 & 12 & 4 & 21 \\
\hline Trace of settlement & 218 & 33 & 39 & 13 & 303 \\
\hline Others & 17 & 5 & 9 & 2 & 33 \\
\hline Total & 507 & 63 & 116 & 21 & 707 \\
\hline
\end{tabular}

Table 2. Sandomierz Upland - the main features of the spatial distribution of settlement points of the Funnel Beaker and Globular Amphora cultures

(according to Kowalewska-Marszałek 1992: Table 32).

\begin{tabular}{|c|c|c|c|c|}
\hline \multirow{2}{*}{ Taxonomic unit } & \multirow{2}{*}{$\begin{array}{l}\text { Number of settle- } \\
\text { ment points *) }\end{array}$} & \multicolumn{2}{|c|}{$\begin{array}{l}\text { Number of settlement points per } \\
\qquad 10 \mathrm{~km}^{2}\end{array}$} & \multirow{2}{*}{$\begin{array}{c}\text { Average surface } \\
\text { per } 1 \text { settlement } \\
\text { point (in } \mathbf{k m}^{2} \text { ) }\end{array}$} \\
\hline & & Average & Maximum & \\
\hline Funnel Beaker culture & 455 & 5.9 & 11.7 & 1.7 \\
\hline Globular Amphora culture & 102 & 1.3 & 2.8 & 7.6 \\
\hline
\end{tabular}

*) for area systematically investigated $\left(773 \mathrm{~km}^{2}\right)$

The so-called upland settlements are a special category. They are located in places of natural defensive value, but generally without traces of additional defensive constructions ${ }^{5}$ that are known only from the settlement in Stryczowice (Uzarowicz-Chmielewska

5 The aforementioned lack of defensive fortifications is not entirely certain due to the incomplete exploration of the sites and the research strategy used, involving excavations of the central rather than peripheral parts of settlements (Podkowińska 1950: 95 ff.; I95I/52: 20I ff.; 1962: 98; Kempisty 1965: 245 ff.; Balcer 1967: 290 ff.). Therefore, the existence of this type of construction cannot be definitely excluded. 
Table 3. Sandomierz Upland - features of distribution of settlement points according to analysis with Clark-Evans' method (according to Kowalewska-Marszałek I992: Tab. 33, 34).

\begin{tabular}{|c|c|c|c|c|}
\hline Taxonomic unit & Region & Settlement points & $\begin{array}{c}\text { R-coefficient } \\
\text { (according to } \\
\text { Clark-Evans test) }\end{array}$ & $\begin{array}{c}\text { Distribution } \\
\text { pattern }\end{array}$ \\
\hline \multirow{6}{*}{$\begin{array}{l}\text { Funnel Beaker } \\
\text { culture }\end{array}$} & \multirow{3}{*}{ Total area $*$ ) } & All & 0.87 & $\begin{array}{c}\text { Poorly } \\
\text { agglomerated }\end{array}$ \\
\hline & & $\begin{array}{c}\text { Medium-size } \\
\text { settlements }\end{array}$ & 2.02 & Regular \\
\hline & & $\begin{array}{l}\text { Large-size } \\
\text { settlements }\end{array}$ & 1.90 & Regular \\
\hline & Northern zone & All & 1.28 & Random / regular \\
\hline & Central zone & All & 0.84 & $\begin{array}{c}\text { Poorly } \\
\text { agglomerated }\end{array}$ \\
\hline & Southern zone & All & 0.98 & Random \\
\hline \multirow{2}{*}{$\begin{array}{l}\text { Globular } \\
\text { Amphora } \\
\text { culture }\end{array}$} & Total area*) & All & 0.88 & $\begin{array}{c}\text { Poorly } \\
\text { agglomerated }\end{array}$ \\
\hline & Zone A & All & 0.83 & $\begin{array}{c}\text { Poorly } \\
\text { agglomerated }\end{array}$ \\
\hline
\end{tabular}

*) area systematically investigated $\left(773 \mathrm{~km}^{2}\right)$

1982; Uzarowicz-Chmielewska and Sałacińska 20I3: 227). Other upland settlements ${ }^{6}$ are only large or very large sites, usually characterised by a high intensity of use; all of them also revealed traces of earlier settlement. The smallest among them, with an area of about 2 ha, is the settlement in Nikisiałka Duża (Kupczyk 1970: 98).

Two upland settlements, of among the biggest in the Sandomierz Upland area, Ćmielów site I and the Pieczyska site in Zawichost-Podgórze, are also important production sites ${ }^{7}$ related to the flint mines of the eastern Łysogóry region and large scale flint processing (Balcer 1975: I78 ff.; 2002: I47 ff.). The settlement in Ćmielów was focused on the processing of banded and Świeciechów flint, the settlement in Zawichost - on the processing of Świeciechów flint. The hypothesis about the participation of the inhabitants of the settlement in Ćmielów in specialised mining exploitation of banded flint and their relationships with the mines in Krzemionki Opatowskie, Ostrowiec Świętokrzyski district, has existed in the literature for a long time (Krukowski 1939: 84 ff.;

${ }^{6}$ Such as Ćmielów site I ("Gawroniec”) and Grzegorzowice site Zagaje - Ostrowiec Świętokrzyski district, Nikisiałka Duża site I and Ptkanów site I - Opatów district, Gorzyczany site II, Kamień Łukawski site I, Zawichost-Podgórze site Pieczyska - Sandomierz district.

7 As defined by B. Balcer (1975: 178 ff.). 
I24 Hanna Kowalewska-Marszatek

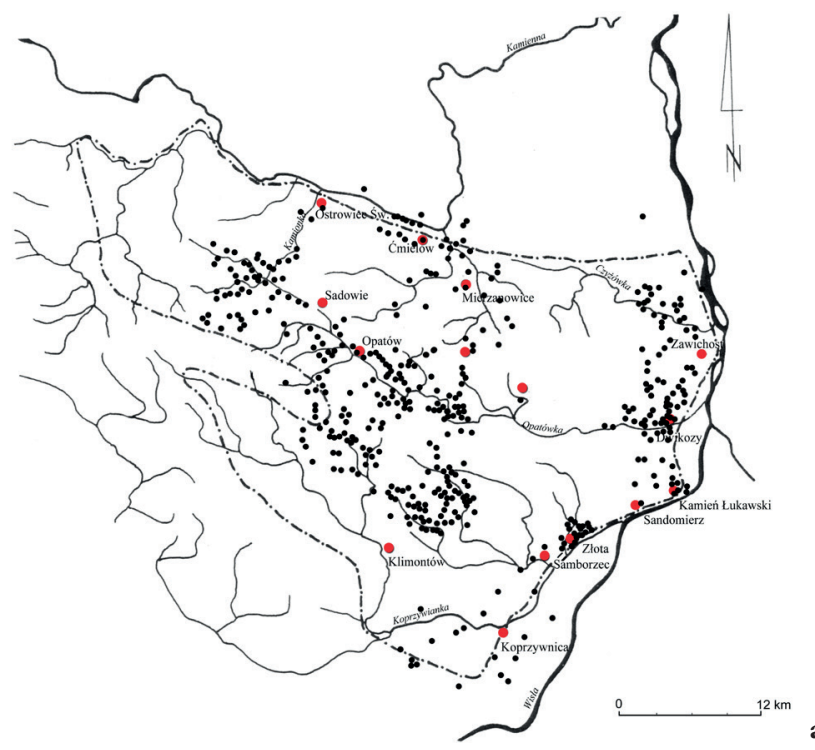

a.

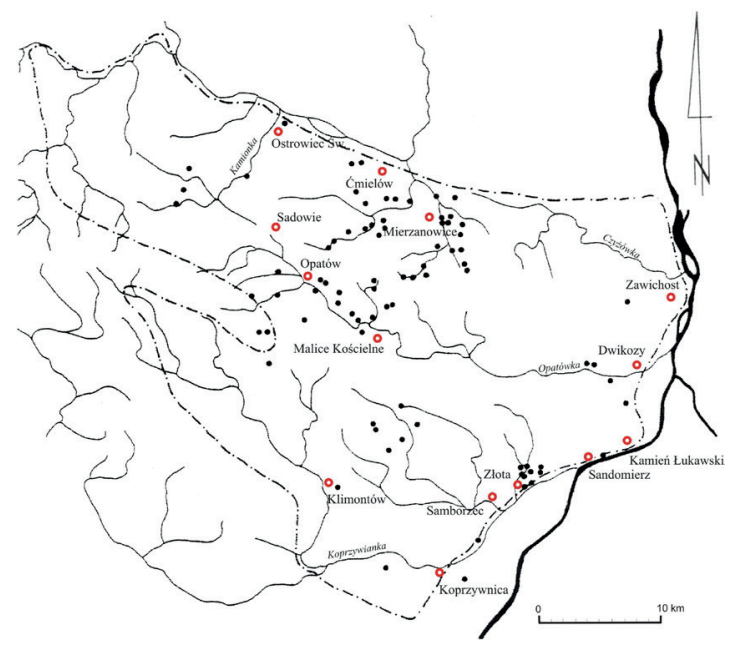

b.

Fig. I. Sandomierz Upland. Maps of distribution of settlement points of the Funnel Beaker culture (a) and of the Globular Amphora culture (b). 


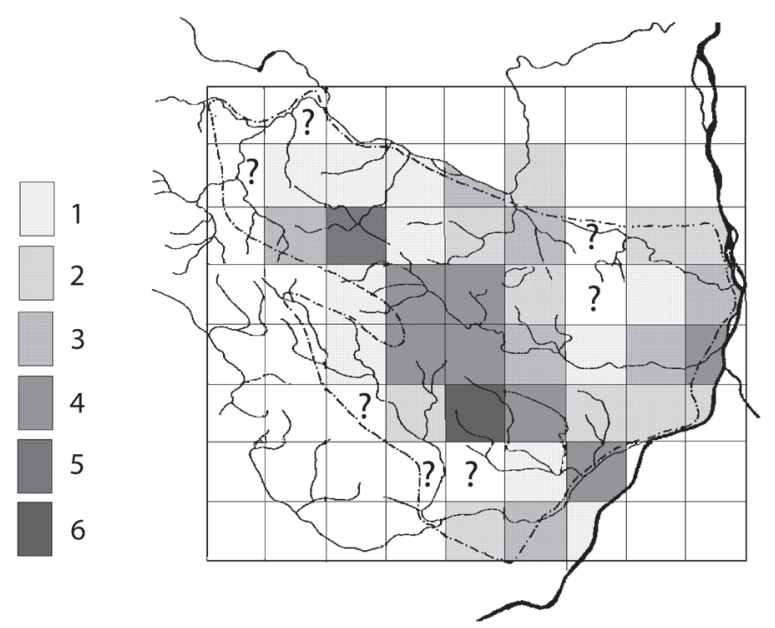

a.

Fig. 2a. Sandomierz Upland. Distribution diagram of settlement points of the Funnel Beaker culture.

Legend: I: <5 sites per $36 \mathrm{~km}^{2}$; 2: 5-IO sites per $36 \mathrm{~km}^{2}$; $3:$ II-20 sites per $36 \mathrm{~km}^{2}$; 4: 2I-30 sites per $36 \mathrm{~km}^{2}$; 5: 3I-40 sites per $36 \mathrm{~km}^{2} ; 5:>40$ sites per $36 \mathrm{~km}^{2}$; ?: no data available

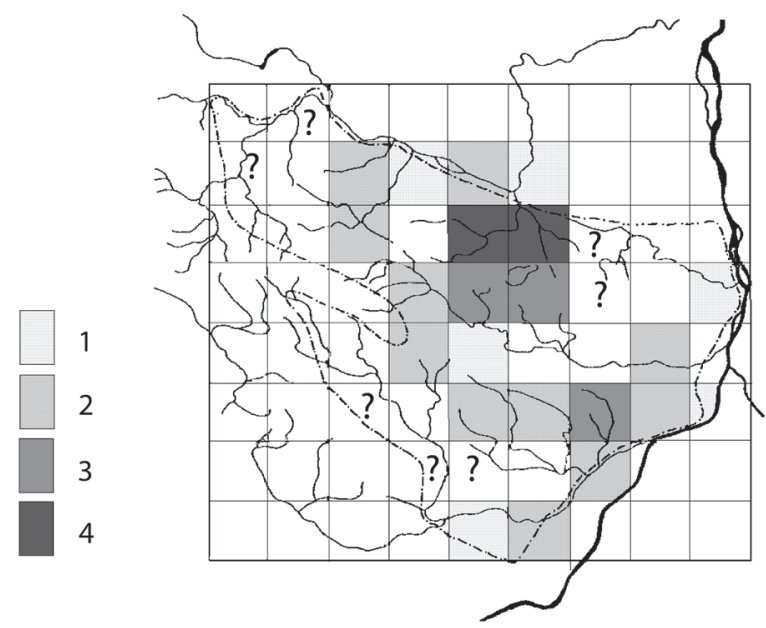

b.

Fig. 2b. Sandomierz Upland. Distribution diagram of settlement points of the Globular Amphora culture.

Legend: I: I site per $36 \mathrm{~km}^{2} ; 2: 2-5$ sites per $36 \mathrm{~km}^{2} ; 3: 6-$ IO sites per $36 \mathrm{~km}^{2}$; 4 : >IO sites per $36 \mathrm{~km}^{2}$; ?: no data available. 
I26 Hanna Kowalewska-Marszatek

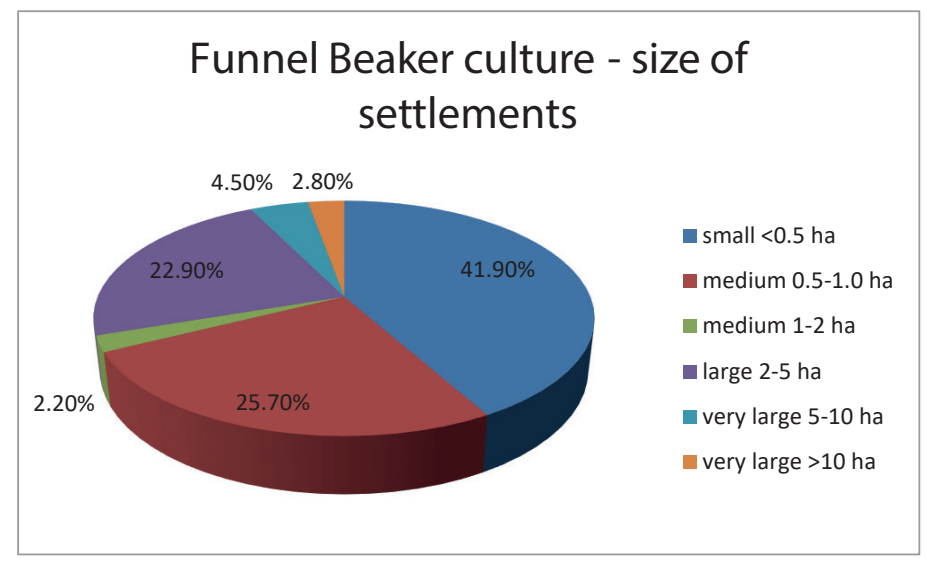

a.

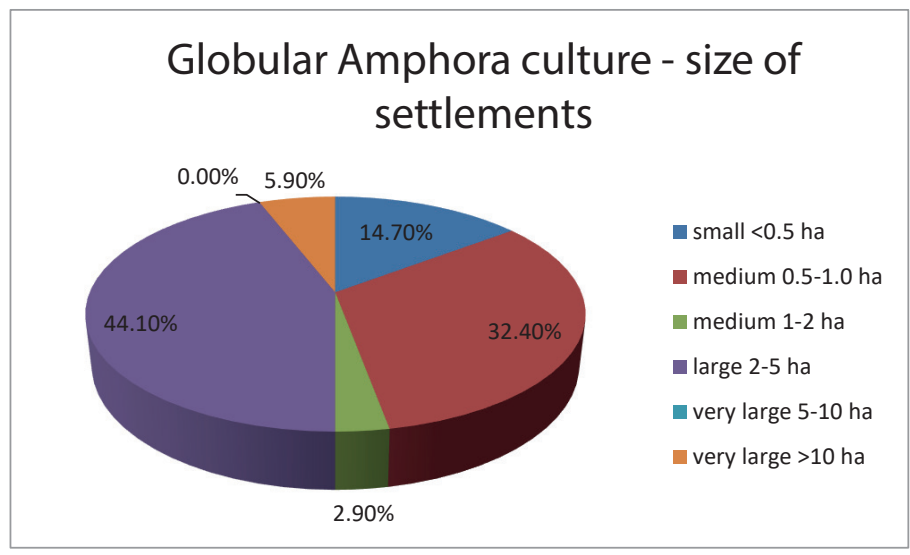

b.

Fig. 3. Sandomierz Upland. Size structure of settlements of the Funnel Beaker culture (a) and of the Globular Amphora culture (b).

Podkowińska 1950: 132; Krzak 1961: 29 ff.; Balcer 1975: I80 ff.), though there was also some skepticism about it from, among others, J. Kowalczyk (Kowalczyk 1962: 306). However, the latest findings of Bogdan Balcer have allowed for a much stronger grounding of this hypothesis (Balcer 2002: 147). This researcher also showed that the relationship between the settlement [on Gawroniec hill] and the exploitation of the deposits of the Swieciechów raw material was equally strong and even more important (Balcer 2002: I47). In addition, in his opinion, the settlement on Gawroniec can be described as the most 
specialised production centre in the field of mining and fint processing not only in the Swiętokrzyski region, but within the even wider extent of the Funnel Beaker culture (Balcer 2002: I6I).

In the light of settlement studies, the role of the upland settlements is not clear. Despite the basic common feature, which is their "defensive" location, they form a group quite diverse in size, nature, and - probably - in terms of the duration of functioning. The stability of many of them, which is largely the result of being located in favourable environmental conditions, undoubtedly had an impact on the more durable nature of connections with other elements of the settlement network. However, it seems that interpreting these sites as "outstanding regional centres" (Kowalczyk 1962: 304-306; Kruk 1980: IOO) is only partially justified and concerns primarily their rank. On the other hand, it is hard to consider upland settlements as "central" points of the settlement network, due to their peripheral location in relation to the most intensive settlement zones, as well as due to the lack of particular concentrations of settlement points in their immediate surroundings. These settlements sometimes are even in some isolation from the others (e.g. Zawichost, Sandomierz district), while being elements of a network of large settlements regularly distributed throughout the Upland (Kowalewska-Marszałek 1992; 20I2; 20I8: Fig. 6).

The settlement network of the Funnel Beaker culture exhibits features that are fundamentally different from the previous "Danubian" settlement pattern (Kowalewska-Marszałek 2007). It is characterised by high uniformity (despite the abovementioned zonation), as well as preferring regions with similar environmental conditions (Kowalewska-Marszałek 20I8: 320). Shifting the "centre of gravity" of the settlement to the northern and central regions of the discussed area could be justified by the connection of sites from this period with the exploitation and processing of flint raw materials: the banded and the Świeciechów flints outcrops of which are located in the north and northeast of the Upland (Schild 1971; Balcer 1975: 147). It cannot be excluded that more intensely used areas were not occupied (or occupied to a lesser extent) by settlements belonging to the late phases of the cultures of the Lengyel-Polgár cycle, with the very likely partial coexistence of both cultures in the area. On the other hand, a much larger (compared to the "Danubian" cycle) number of settlement points for the Funnel Beaker culture most likely has demographic justification (Kowalewska-Marszałek I992: 25I-252).

\section{THE SETTLEMENT NETWORK OF THE GLOBULAR AMPHORA CULTURE}

The settlement network of the Globular Amphora culture consists of over Ioo settlement points, among which settlements predominate; camps, workshops, cemeteries, individual graves and traces of settlement are also known (Table I). Their range 
of compact occurrence is limited to the northwestern part of the Sandomierz Upland, from the Kamionka river in the west to the Krzczonowianka river (formerly: Gierczanka river) in the east and the tributaries of the upper and middle Opatówka in the south; small concentrations of sites are also visible on the upper Gorzyczanka and at the Polanówka river in the area of Złota, Sandomierz district. In the eastern and southern parts of the Upland, only single sites of this culture are encountered. They are found in the vicinity of Winiary, Dwikozy and Koprzywnica, Sandomierz district (Fig. Ib). Such a picture, it seems, only to a small extent results from the state of exploration of the area in question, and the lack of sites in its eastern and southern parts (apart from the few exceptions mentioned above) seems to be unquestionable.

Settlement points belonging to the Globular Amphora culture occur together in an area of about $648 \mathrm{~km}^{2}$, which is little more than half of the entire area of the Upland itself. However, the area of their maximum density covers only $180 \mathrm{~km}^{2}$ and coincides with the abovementioned dense range of their occurrence in the watercourse area of: the Przepaść river (formerly: Obręczówka), Krzczonowianka and middle part of Opatówka river (Fig. 2b). This situation is only slightly reminiscent of that observed in the Funnel Beaker culture, where settlement points were connected primarily with the middle part of the Upland.

Cluster analysis based on the shortest distance dendrite (Chojnicki 1977: 107-III), when rejecting distances exceeding $3 \mathrm{~km}$, allows us to distinguish two main zones in the discussed area (Kowalewska-Marszałek 1992: 253):

A - a "central" - macro-cluster along the Krzczonowianka and Przepaść rivers;

B - "peripheral" - covering remaining areas.

The average density for the systematically examined area is 13 sites per $100 \mathrm{~km}^{2}$ (one site per $\left.7.6 \mathrm{~km}^{2}\right)$, therefore it is more than four times smaller than in the case of the Funnel Beaker culture (Table 2).

The analysis of the spatial arrangement of settlement points indicates an agglomerated distribution model, with a moderate degree of concentration, similar to that of the Funnel Beaker culture (Table 3). This applies to both the entire area of sites occurrence and the zone (the macro-cluster) A. Within the latter, quite an even distribution of sites throughout the area is observed, except for the central part (this lack may, however, be due to deficiencies in site discovery). The medium density of settlement points (2.8 points per Io $\mathrm{km}^{2}$ ) is more than twice higher than the average; distances between the sites are small: from 0.3 to $1.4 \mathrm{~km}$, most often $0.6-0.9 \mathrm{~km}$. The eastern border of this zone may, as has been mentioned, undergo some corrections as a result of future studies, while the remaining ones can be determined to a degree that does not raise major doubts.

The "island" character of settlement in zone B also seems to correspond to the real situation. Here small areas of concentrations of sites (and in the southern part individual sites) are separated by strips of land at least $3 \mathrm{~km}$ wide. However, the density 
of sites and the distance between them within individual concentration areas do not differ significantly from those observed in zone A.

The 33 clusters identified during the analysis ${ }^{8}$ have from 2 to 6 sites (most often they are pairs of settlement points), covering an area from 0.4 to $12.5 \mathrm{~km}^{2}$ (in zone A: $2-4$ sites in the area from 0.4 to $2.2 \mathrm{~km}^{2}$ ), with distances between sites from 0.2 to $2.9 \mathrm{~km}$ (average $1.25 \mathrm{~km}$ ). Most often one meets linear arrangements of settlement points. The concentration regions in zone B comprise from I to 3 clusters (Kowalewska-Marszałek I992: 254). The number of sites in individual clusters - as well as the average area of these clusters - is therefore smaller than in the Funnel Beaker culture (Table 4). On the other hand, the distances between settlement points within clusters are similar to those in the northern zone of Funnel Beaker culture.

In one of the clusters in the southern part of the Upland, a specific configuration is visible: settlement points at even, relatively large intervals of $2.5-3.0 \mathrm{~km}$, stretched out in a "line". A thorough examination of the area excludes the randomness of such a system, it also seems to contradict the regular distribution of sites. A similar situation is to be found repeated on the upper Opatówka river (similar distances between the sites with a slightly different arrangement), as well as along the Kamionka river.

Most of the settlements of the Globular Amphora culture (Fig. 2b) are associated with zone $A$, and sites of a different character are encountered there exceptionally. In zone $\mathrm{B}$, the distribution of settlements and settlement points of other kinds is more even: I-2 settlements per cluster. Large settlements (Fig. 3b) usually occur individually, with only two clusters in zone A are connected two large settlements (the cluster of Wojnowice, Ostrowiec Świętokrzyski district, and that of Stodoły, Opatów district).

Cemeteries occurred in zone A, as well as in two clusters of zone B (in the area of Sandomierz and Złota, Sandomierz district), in the immediate vicinity of settlements. In contrast, individual graves are spread throughout the entire area of the occurrence of the Globular Amphora culture, and their location near settlements is not a rule (e.g. grave in Rzeczyca Mokra site I, Sandomierz district, located $2.5 \mathrm{~km}$ from the nearest known settlement).

The settlement system of the Globular Amphora culture is a phenomenon quite different from that of the Funnel Beaker culture. One of the few elements common to both cultures is the heterogeneous character of the settlement network. On the other hand, the arrangement of sites, the way they are combined into complexes, and - probably - the way they had functioned, show many differences.

It seems that the compact settlement zone (A), consisting mainly of settlements occurring in pairs or in ternary systems constituted a spatially developed micro- or mesoregion (Kurnatowski I973: I8), utilised with similar intensity throughout the duration of the Globular Amphora culture and showing characteristics of a stable

\footnotetext{
${ }^{8}$ Using the "nearest neighbour" method (Hodder and Orton 1976: 38-42; Kobyliński 1987: 26-29).
} 
I30 $\mid$ Hanna Kowalewska-Marszatek

Table 4. Sandomierz Upland - characteristics of clusters in individual settlement zones of the Funnel Beaker and Globular Amphora cultures (according to: Kowalewska-Marszałek 1992: Table 35).

\begin{tabular}{|c|c|c|c|c|c|c|}
\hline $\begin{array}{l}\text { Taxonomic } \\
\text { unit }\end{array}$ & Region & $\begin{array}{c}\text { Number of } \\
\text { clusters }\end{array}$ & $\begin{array}{c}\text { Number of } \\
\text { settlement } \\
\text { points in the } \\
\text { cluster } \\
\text { (min./max.) }\end{array}$ & $\begin{array}{l}\text { Average } \\
\text { number of } \\
\text { settlement } \\
\text { points in the } \\
\text { cluster }\end{array}$ & $\begin{array}{c}\text { Average } \\
\text { surface area } \\
\text { of the cluster } \\
\left(\text { in } \mathbf{k m}^{2}\right)\end{array}$ & $\begin{array}{c}\text { Average } \\
\text { distance } \\
\text { among } \\
\text { settlement } \\
\text { points } \\
\text { within the } \\
\text { cluster } \\
\text { (in } \mathrm{km} \text { ) }\end{array}$ \\
\hline \multirow{4}{*}{$\begin{array}{l}\text { Funnel } \\
\text { Beaker } \\
\text { culture }\end{array}$} & $\begin{array}{l}\text { Northern } \\
\text { zone }\end{array}$ & 17 & $2-6$ & 2.94 & 1.59 & 0.83 \\
\hline & $\begin{array}{c}\text { Central- } \\
\text { western zone }\end{array}$ & 67 & $2-8$ & 3.53 & 0.81 & 0.50 \\
\hline & $\begin{array}{l}\text { Central- } \\
\text { eastern zone }\end{array}$ & 35 & $2-6$ & 3.53 & 1.02 & 0.50 \\
\hline & $\begin{array}{l}\text { Southern } \\
\text { zone }\end{array}$ & 8 & $2-5$ & 3.38 & 1.99 & 1.16 \\
\hline $\begin{array}{l}\text { Globular } \\
\text { Amphora } \\
\text { culture }\end{array}$ & Zone A & 19 & $2-4$ & 2.53 & 0.93 & 0.75 \\
\hline
\end{tabular}

territorial organization (large settlements, cemeteries). Therefore, individual groups of sites would rather correspond to the subsequent stages of the functioning of this large system, although connections of functional character cannot be ruled out. On the other hand, the concentration of sites in zone B seems to consist mainly of small settlement complexes (clusters in the area of Usarzów, Opatów district, Sandomierz, Złota and Kichary Nowe - Sandomierz district). On the other hand, linear system of sites noted in the south-eastern and north-western parts of the Upland may constitute traces of occasional penetration into areas not permanently inhabited by the population of the Globular Amphora culture. Alternatively, they could be "staging points" on trade routes, and this seems more likely due to the regularity of their arrangement (Kowalewska-Marszałek 1992: 258).

\section{SUMMARY}

The analysis of the spread of settlement points of both analysed taxonomic units allows us to state the clear differences between them. Sites of the Funnel Beaker culture occur throughout the entire study area, with a tendency to form discret clusters in the 
central and eastern parts of the region, while the Globular Amphora culture sites are mainly in its northern part. There is also a difference in the spread of sites of both cultures in relation to earlier "Danubian" cultures, whose settlement points were concentrated in the south-eastern and eastern parts of the Upland (in the Vistula zone), with a complete absence on the north-eastern edges (Kowalewska-Marszałek 2007). This is probably due to the disappearance in this period of the earlier southern direction of far-reaching contacts and impacts.

The settlement network transformed, from a relatively homogeneous one in the early Neolithic, into a heterogeneous form as a result of the emergence in the Funnel Beaker culture of new categories of sites: several types of settlements, separate cemeteries and flint workshops.

Along with the transformations of settlement structures there was a shift in the nature of their links with the natural environment. Initially, the main role was played by the Vistula and its tributaries in the southern part of the Upland; beginning from the time of the Funnel Beaker culture, the watercourses in its northern part were gaining in importance. Two special trends are visible in the location of settlements relative to soils: in the Funnel Beaker culture we observe the desire to maximise the use of all soil types,, in the arrangement related to the Globular Amphora culture, there is more of a tendency to closely link the settlements to selected soil types and to the areas of their "mosaic"-like occurrence. On the other hand, there is a tendency to locate settlements, especially large ones, in such a way that their "closer" exploitation territories (Higgs and Vita-Finzi 1972; Jarman 1972; see also Kowalewska-Marszałek 1988) extend over several different habitat zones. In this way, efforts were probably made to maximise access to a variety of natural resources.

The analysed period seems to be a time of a fundamental change in the nature of the settlement network, consisting of changes in the integral treatment of space (KowalewskaMarszałek 1992: 296-297). This is reflected in the way the settlements are developed, and, to a greater extent, in the structure of the regional settlement network. The latter exhibits features of planned territorial organization and spacial stabilization, visible above all in the increasing regularity of the distribution of settlements, especially large and medium-sized ones, throughout the entire culture area of the Funnel Beaker culture, as well as in the isolation of additional permanent points in the form of cemeteries, generally used on a continuous basis until the early Bronze Age?.

The intensive exploitation of banded flint in the Late Stone Age undoubtedly required the existence of a settlement base in close proximity to the mines of this raw material. There is a lot of evidence that this role was primarily played by the Sandomierz

9 A "functional" treatment of collective graves - also megalithic tombs - as fixed points of space and territory markers in the Neolithic European communities with the dispersed settlement model is one of the currently accepted possibilities of their interpretation (e.g. Renfrew and Bahn I99I: 428). 
I32 $\mid$ Hanna Kowalewska-Marszatek

Upland, which comprises the natural context for the functioning of the flint mines located in the Krzemionki area, Ostrowiec Świętokrzyski district, especially in the Middle and Late Neolithic period and in the early Bronze Age. Its crucial role in this context has often been indicated in the literature on the subject (e.g. Krukowski 1939: 84-97; Wiślański 1969: 246-248; Balcer 1975: 247; Kruk 1980: 105). A detailed analysis of middle and late Neolithic settlements fully confirms the thesis about the significant role of the Sandomierz Upland as a settlement base for the banded flint mines in the Krzemionki region. Considering all the analysed features of the settlement network in this area, it can be stated that the relationship with banded flint mines is more pronounced in the case of the Globular Amphora culture. This is evidenced above all by the clear concentration of sites of this culture in the northern part of the Upland, in the immediate vicinity of the raw material outcrops, in the context of an absence of similar concentrations in other regions. Such a clear accumulation of settlement sites is lacking in the Funnel Beaker culture, while large settlements of this culture (e.g. Ćmielów-Gawroniec or Stryczowice site I, Ostrowiec Świętokrzyski district) show only a partial connection with the processing of banded flint (Balcer 2002: I47; Sałaciński 2013: 257 ff.).

The macro-cluster of the Globular Amphora culture sites in zone A was undoubtedly primarily associated with the exploitation of banded flint. The concentration of settlements testified there is yet another argument to support the hypothesis about the intensive exploitation of mines in the Krzemionki area by the communities of this culture and the participation of these human groups in the exchange on a large, supra-regional scale (Balcer and Kowalski 1978: 137; Balcer 1983: 208, 223-226; 2002: 20; Borkowski 1995: 15).

Translated by Andrzej Leligdowicz

\section{REFERENCES}

Balcer, B. 1967. Stanowisko Pieczyska (Zbrza Wielka) w Zawichoście-Podgórzu, pow. Sandomierz, w świetle pierwszych wykopalisk. Wiadomości Archeologiczne 32: 290-375.

Balcer, B. I97I. Kopalnia krzemienia w Świeciechowie-Lasku, pow. Kraśnik w świetle badań 1967 r. Wiadomości Archeologiczne 36(I): 7I-I32.

Balcer, B. 1975. Krzemień świeciechowski w kulturze pucharów lejkowatych. Eksploatacja, obróbka i rozprzestrzenienie. Wrocław-Warszawa-Kraków-Gdańsk.

Balcer, B. 1983. Wytwórczość narzędzi krzemiennych w neolicie ziem Polski, Zusamm.: Die Herstellung von Feuersteingeräten im Neolithikum auf dem Gebiet Polens. Wrocław-Warszawa-Kraków-GdańskŁódź.

Balcer, B. 2002. Ćmielów - Krzemionki-Świeciechów. Związi osady neolitycznej z kopalniami krzemienia, Sum. Relations between the neolithic settlement and fint mines. Warszawa. 
Balcer, B. and Kowalski, K. 1978. Z badań nad krzemieniem pasiastym w pradziejach. Wiadomości Archeologiczne 43: 127-I45.

Borkowski, W. 1995. Krzemionki mining complex. Deposit management system. Warszawa. Studia nad Gospodarką Surowcami Krzemiennymi w Pradziejach 2.

Chojnicki, Z. 1977. Metody ilościowe i modele w geografii. Warszawa.

Godłowski, K. I964. Z badań nad rozwojem osadnictwa kultury przeworskiej na Górnym Śląsku. Archeologia Polski 9(2): 400-429.

Higgs, E. S. and Vita-Finzi, C. V. 1972. Prehistoric economies; a territorial approach. In E. S. Higgs (ed.), Papers in Economic Prehistory, 27-31. Cambridge.

Hodder, I. and Orton, C. 1976. Spatial Analysis in Archaeology. Cambridge.

Jarman, M. R., 1972. A territorial model for archaeology: a behavioral and geographical approach. In D. L. Clarke (ed.), Models in Archaeology, 705-733. London.

Kempisty, E. 1965. Sprawozdanie z prac wykopaliskowych przeprowadzonych w 1962 r. na osadzie kultury pucharów lejkowatych w Kamieniu Łukawskim, pow. Sandomierz. Wiadomości Archeologiczne 3I: 245-246.

Kobyliński, Z. 1987. Podstawowe metody analizy przestrzennej układów punktowych. Archeologia Polski 32: $2 \mathrm{I}-53$.

Kondracki, J. 1978. Geografia fizyczna Polski. Warszawa.

Kowalczyk, J. 1962. "Sondaż terenowy" w badaniach archeologicznych. Wiadomości Archeologiczne 28(4): 30I-307.

Kowalewska-Marszałek, H. 1988. L'approche territoriale dans les études de l'habitat. Quelques remarques. Bulletin du Centre Genèvois d'Anthropologie I: 7-I4.

Kowalewska-Marszałek, H. 1992. Osadnictwo neolityczne na Wyżynie Sandomierskiej. Unpublished PhD thesis, the Institute of Archaeology and Ethnology Polish Academy of Sciences. Warszawa.

Kowalewska-Marszałek, H. 2007. The "Lengyel-Polgár" settlement in the Sandomierz Upland. Microregional studies. In J. K. Kozłowski and P. Raczky (eds), The Lengyel, Polgár and related cultures in the Middle/Late Neolithic in Central Europe, 43I-448. Kraków.

Kowalewska-Marszałek, H. 20I2. Neolithic fortified sites and settlement patterns on the Sandomierz Loess Upland. In F. Bertemes and H. Meller (eds), Neolitische Kreisgrabenanlagen in Europa / Neolithic Circular Enclosures in Europe (Internationale Arbeitstagung vom 7. Bis 9. Mai 2004 in Goseck (Sachsen-Anhalt) / International Workshop 7th - 9th May 2004 in Goseck (Saxony-Anhalt, Germany), 327-338. Halle (Saale). Tagungen des Landesmuseums für Vorgeschichte Halle 8.

Kowalewska-Marszałek, H. 20I8. From the research on the Funnel Beaker culture in the Sandomierz Upland (on the occasion of the considerations by Konrad Jażdzewski). Prace i Materiaty Muzeum Archeologicznego i Etnograficznego w Eodzi, Seria Archeologiczna 47(2016-2017): 309-326.

Kruk, J. 1973. Studia osadnicze nad neolitem wyżnn lessowych. Wrocław.

Kruk, J. 1980. Gospodarka w Polsce potudniowo-wschodniej w V-III tysiacleciu p.n.e. Wrocław-WarszawaKraków.

Krukowski, S. 1939. Krzemionki Opatowskie. Warszawa.

Krzak, Z. 196r. Sprawozdanie z badań powierzchniowych w województwach kieleckim i lubelskim w latach 1954-1959. Sprawozdania Archeologiczne 13: 29-44.

Kupczyk, I. 1970. Osadnictwo neolityczne i z początku epoki brązu w górnym dorzeczu Opatówki. Unpublished MA thesis, University of Warszawa.

Kurnatowski, S. 1973. Zakres przestrzenny archeologicznych badań terenowych a przydatność ich dla analizy osadniczej. Biuletyn Informacyjny PKZ 25: 9-39.

Nowak, M. 2009. Drugi etap neolityzacji ziem polskich. Kraków. 
I34 | Hanna Kowalewska-Marszatek

Podkowińska, Z. 1950. Osada neolityczna na górze “Gawroniec” w Ćmielowie pow. Opatów. Wiadomości Archeologiczne 17: 95-I42.

Podkowińska, Z. 1951/52. Prace wykopaliskowe na stanowisku "Gawroniec-Pałyga" w Ćmielowie w pow. opatowskim 1950 r. Wiadomości Archeologiczne 18: 20I-242.

Podkowińska, Z. 1962. Village éneolithique de Ćmielów, district Opatów, voïvodie de Kielce. Archaeologia Polona 4: 98-III.

Renfrew, C. and Bahn, P. 1991. Archaeology. London.

Sałaciński, S. 20I3. Materiały krzemienne z badań neolitycznych stanowisk w Stryczowicach, woj. świętokrzyskie. In A. Uzarowicz-Chmielewska and B. Sałacińska, Osady neolityczne w Stryczowicach, woj. świętokrzyskie, 257-285. Warszawa. Materiały Starożytne i Wczesnośredniowieczne Io.

Schild, R. 1971. Lokalizacja prahistorycznych punktów eksploatacji krzemienia czekoladowego na północnowschodnim obrzeżeniu Gór Świętokrzyskich. Folia Quaternaria 39: I-6I.

Tabaczyński, S. 1970. Neolit środkowoeuropejski. Podstawy gospodarcze. Wrocław-Warszawa-Kraków.

Uzarowicz-Chmielewska, A. 1982. Fosa obronna na osadzie kultury pucharów lejkowatych w Stryczowicach, woj. Kielce, w świetle czteroletnich badań wykopaliskowych. Wiadomości Archeologiczne 47(2): $245-266$.

Uzarowicz-Chmielewska, A. and Sałacińska, B. 20I3. Osady neolityczne w Stryczowicach, woj. świętokrzyskie. Warszawa. Materiały Starożytne i Wczesnośredniowieczne io.

Wiślański, T. 1969. Podstawy gospodarcze plemion neolitycznych w Polsce pótnocno-zachodniej. Wrocław. 